\title{
Sulfurihydrogenibium kristjanssonii sp. nov., a hydrogen- and sulfur-oxidizing thermophile isolated from a terrestrial Icelandic hot spring
}

Correspondence Anna-Louise Reysenbach reysenbacha@pdx.edu
The order Aquificales, which comprises thermophiles belonging to the families Aquificaceae, Desulfurobacteriaceae and Hydrogenothermaceae, is considered to be one of the deepest branching lineages of the domain Bacteria (Burggraf et al., 1992; Pitulle et al., 1994; Di Giulio, 2003a, b, c; Barion et al., 2007). Members of two of these families, the Aquificaceae and the Hydrogenothermaceae, are widespread in terrestrial hydrothermal systems and include those belonging to the genera Hydrogenobaculum, Hydrogenobacter, Sulfurihydrogenibium and Thermocrinis (Reysenbach et al., 2000; Skirnisdottir et al., 2000; Takacs et al., 2001; Spear et al., 2005; Purcell et al., 2007; Hetzer et al., 2007; Ferrera et al., 2007). Most representatives of these genera appear as filamentous biomass in hot-spring streams and are often associated with sulfur or iron deposits (Reysenbach et al., 2005). Recently, several members of the genus Sulfurihydrogenibium have

The GenBank/EMBL/DDBJ accession number for the partial 16S rRNA gene sequence of strain $16628^{\top}$ is AM778960.

Graphs showing the effects of temperature and $\mathrm{pH}$ on growth of strain $16628^{\top}$ are available as supplementary figures with the online version of this paper. been isolated from hydrothermal systems in geographically diverse locations, including Japan (Sulfurihydrogenibium subterraneum HGMK-1 ${ }^{\mathrm{T}}$; Takai et al., 2003), the Azores (Sulfurihydrogenibium azorense Az-Fu1 ${ }^{\mathrm{T}}$; Aguiar et al., 2004), Yellowstone National Park (USA) (Sulfurihydrogenibium yellowstonense SS- $5^{\mathrm{T}}$; Nakagawa et al., 2005), New Zealand (strain CP.B2; Hetzer et al., 2007) and Kamchatka, Russia (Sulfurihydrogenibium rodmanii UZ3-5 $5^{\mathrm{T}}$; O'Neill et al., 2008). These studies have identified physiological properties common among members of this genus; several differences have also been revealed. For example, all described isolates are able to oxidize $\mathrm{S}^{0}$ and $\mathrm{S}_{2} \mathrm{O}_{3}^{2-}$ with $\mathrm{O}_{2}$ acting as an electron acceptor, but only $S$. azorense Az$\mathrm{Fu}^{\mathrm{T}}{ }^{\mathrm{T}}$, S. subterraneum HGMK-1 ${ }^{\mathrm{T}}$ and strain CP.B2 can also oxidize $\mathrm{H}_{2}$ (Takai et al., 2003; Aguiar et al., 2004; Nakagawa et al., 2005; Hetzer et al., 2007; O'Neill et al., 2008). Clone libraries of $16 \mathrm{~S}$ rRNA gene sequences from Icelandic hotspring filaments identified relatives of Sulfurihydrogenibium (Skirnisdottir et al., 2000), and here we report the isolation of a novel member of the genus Sulfurihydrogenibium obtained from Iceland. The isolation of this novel species serves to expand the known geographical distribution and metabolic diversity of the genus Sulfurihydrogenibium. 
Thick, grey filaments were collected along the outflow channel of an Icelandic hot spring near the town of

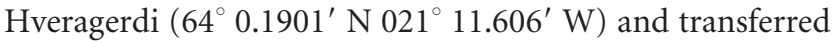
into sterile $150 \mathrm{ml}$ serum bottles. The temperature and $\mathrm{pH}$ at the sampling site were $68{ }^{\circ} \mathrm{C}$ and approximately 6.0. Subsamples were later used to enrich for microaerophilic sulfur-oxidizers in $5 \mathrm{ml}$ modified MS medium, described below (Boone et al., 1989). Enrichment cultures were incubated at $70{ }^{\circ} \mathrm{C}$ and monitored for changes in turbidity. Within $24 \mathrm{~h}$, cultures appeared turbid and were examined for growth by using phase-contrast microscopy. Several of the cultures, i.e. those comprising strains $\mathrm{I}_{6628^{\mathrm{T}}}$, I66735 and I6517, exhibited growth in the form of motile rods. Cultures were subsequently purified by several series of dilution-to-extinction transfers and their purity was verified by $16 \mathrm{~S}$ rRNA gene sequencing. The three isolates were $>99 \%$ identical on the basis of partial 16S rRNA gene sequences, and strain $16628^{\mathrm{T}}$ was selected for further characterization.

The medium used for the isolation and characterization of strain $16628^{\mathrm{T}}$ was modified MS medium (Boone et al., 1989) and contained the following $\left(1^{-1}\right): 5 \mathrm{~g}$ elemental sulfur, $0.8 \mathrm{~g} \mathrm{NaOH}, 0.48 \mathrm{~g} \mathrm{KCl}, 1 \mathrm{~g} \mathrm{MgCl}_{2} .6 \mathrm{H}_{2} \mathrm{O}, 7 \mathrm{~g}$ $\mathrm{MgSO}_{4} \cdot 7 \mathrm{H}_{2} \mathrm{O}, 2 \mathrm{~g} \mathrm{Na}_{2} \mathrm{~S}_{2} \mathrm{O}_{3} \cdot 5 \mathrm{H}_{2} \mathrm{O}, 0.48 \mathrm{~g} \mathrm{CaCl}_{2} \cdot 2 \mathrm{H}_{2} \mathrm{O}$, $0.2 \mathrm{~g} \mathrm{NH}_{4} \mathrm{Cl}, 0.4 \mathrm{~g} \mathrm{~K} \mathrm{HPO}_{4} \cdot 3 \mathrm{H}_{2} \mathrm{O}$ and $10 \mathrm{ml}$ trace element stock solution (Ferguson \& Mah, 1983). The medium was prepared with distilled water under constant bubbling with $\mathrm{CO}_{2}$. The $\mathrm{pH}$ was adjusted to 6.0 with sulfuric acid prior to autoclaving at $105{ }^{\circ} \mathrm{C}$ for $60 \mathrm{~min}$ to prevent melting of the elemental sulfur. After autoclaving, oxygen was added to a final concentration of $4 \%(\mathrm{v} / \mathrm{v})$.

Routine observations of the three isolates were made using an Olympus BX60 phase-contrast microscope. Further detailed examination of strain $16628^{\mathrm{T}}$ was done using electron microscopy as described previously (Nakagawa et al., 2005). In brief, for thin sectioning, cells were fixed in $2 \%(\mathrm{v} / \mathrm{v})$ glutaraldehyde followed by $2 \%(\mathrm{w} / \mathrm{v})$ osmium tetroxide and staining en bloc with $2 \%(\mathrm{w} / \mathrm{v})$ uranyl acetate, as outlined by Beveridge et al. (2007). Cells were dehydrated through an ethanol series and embedded in LR White resin. Once sectioned, cell samples were mounted on carbon- and Formvar-coated 200-mesh grids and stained with uranyl acetate and lead citrate. For negative stains, the grids were coated with a thin suspension of cells, blotted dry and stained with $2 \%$ uranyl acetate. All transmission electron microscopy was done with a Philips CM10 microscope operating at $80 \mathrm{kV}$ under standard operating conditions.

As shown by the thin sections, cells of strain $16628^{\mathrm{T}}$ were Gram-negative, motile, straight to slightly curved rods with a mean length of 1.5-2.5 $\mu \mathrm{m}$ and a width of approximately $0.5 \mu \mathrm{m}$ (Fig. 1a). Cells sometimes possessed humps along their length, indicating some pleomorphism (Fig. 1b). Cells occurred singly or in filaments, each consisting of a few cells (not shown). Flagella were apparent on negatively stained cells, especially at the poles (Fig. 1a). Thin sections
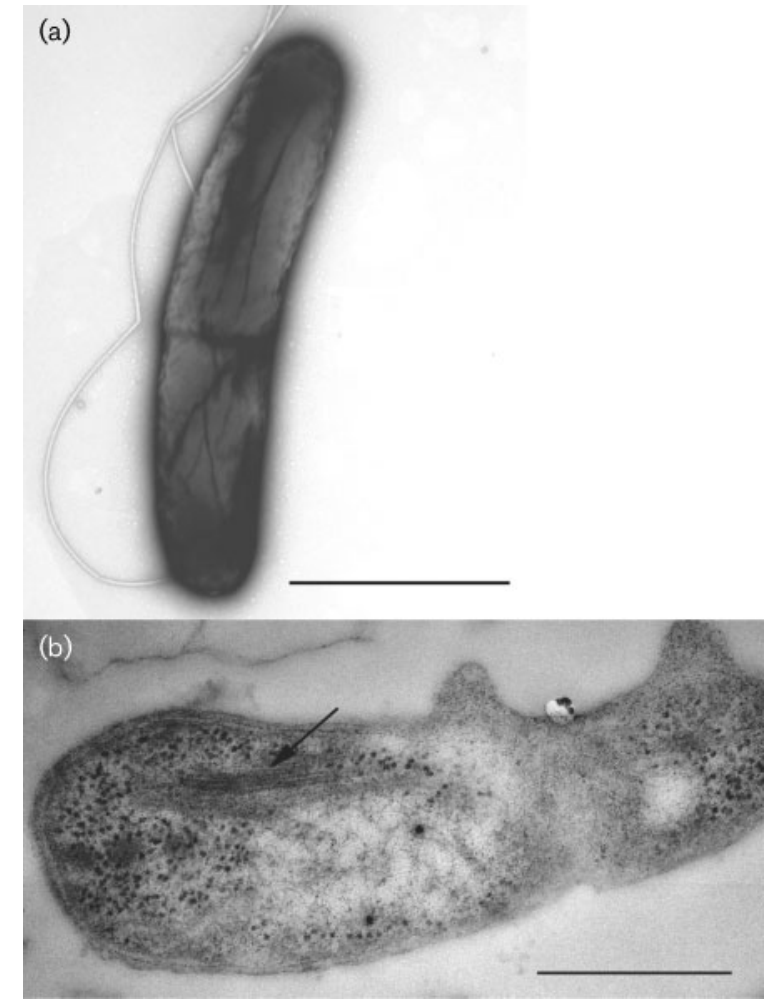

Fig. 1. Electron micrographs of a negatively stained cell (a) and a thin section (b) of strain $16628^{\top}$. Internal membranes or fibres are indicated by arrows in (b). Bars, $1 \mu \mathrm{m}$ (a) and $500 \mathrm{~nm}$ (b).

also revealed the presence of internal stacked membranes or fibres, as has been reported for other members of the Aquificales (Götz et al., 2002; Aguiar et al., 2004) (Fig. 1b). However, the function of these structures remains unclear.

Growth of the isolate was monitored from direct cell counts using a Petroff-Hauser counting chamber viewed with phase-contrast microscopy. All characterization experiments were conducted in sealed $25 \mathrm{ml}$ Balch tubes containing $5 \mathrm{ml}$ modified MS medium inoculated from fresh overnight cultures at $5 \%(\mathrm{v} / \mathrm{v})$. Temperature, $\mathrm{pH}$, electron donor/acceptor and carbon-substrate experiments were conducted in triplicate, while $\mathrm{O}_{2}$ and $\mathrm{NaCl}$ experiments were conducted in duplicate. Unless stated otherwise, all cultivation experiments were conducted in a $68{ }^{\circ} \mathrm{C}$ water bath, at $\mathrm{pH} 6.0$ and $4 \% \mathrm{O}_{2}(\mathrm{v} / \mathrm{v})$.

Growth of strain $16628^{\mathrm{T}}$ was observed at temperatures between 40 and $73{ }^{\circ} \mathrm{C}$; optimal growth occurred at $68{ }^{\circ} \mathrm{C}$ (see Supplementary Fig. S1, available in IJSEM Online). The doubling time and mean cell density reached at $68{ }^{\circ} \mathrm{C}$ were about $95 \mathrm{~min}$ and $1.85 \times 10^{8}$ cells $\mathrm{ml}^{-1}$. To determine the effect of $\mathrm{pH}$ on growth, the $\mathrm{pH}$ of the medium was adjusted by altering the level of $\mathrm{CO}_{2}$ saturation by changing the $\mathrm{NaOH}$ concentration and gassing the medium under different ratios of $\mathrm{CO}_{2}$ and $\mathrm{N}_{2}$ (Chong et al., 2002). Sulfuric acid was used for $\mathrm{pH}$ values below 
6.2. For $\mathrm{pH}$ values above 7.3, the MS medium was further modified by decreasing the amounts of $\mathrm{K}_{2} \mathrm{HPO}_{4} \cdot 3 \mathrm{H}_{2} \mathrm{O}$ $\left(0.2 \mathrm{~g} \mathrm{l}^{-1}\right), \quad \mathrm{MgSO}_{4} \cdot 7 \mathrm{H}_{2} \mathrm{O}\left(0.4 \mathrm{~g} \mathrm{l}^{-1}\right)$ and eliminating $\mathrm{CaCl}_{2} \cdot 2 \mathrm{H}_{2} \mathrm{O}$ and $\mathrm{MgCl}_{2} \cdot 6 \mathrm{H}_{2} \mathrm{O}$ from the medium. This was done to eliminate precipitates and did not appear to affect growth, as growth rates were consistent with those obtained at lower $\mathrm{pH}$ (data not shown). Growth of the isolate at $68{ }^{\circ} \mathrm{C}$ was observed between pH 5.3 and 7.8, with optimal growth at $\mathrm{pH} 6.6$ (see Supplementary Fig. S2, available in IJSEM Online). The doubling time and mean cell density at pH 6.6 and $68{ }^{\circ} \mathrm{C}$ were about $100 \mathrm{~min}$ and $4.0 \times 10^{8}$ cells $\mathrm{ml}^{-1}$. Salt tolerance was tested by injecting defined amounts of $\mathrm{NaCl}(0-3 \%, w / v)$ into MS medium (pH 6) for incubation in a water bath at $68{ }^{\circ} \mathrm{C}$. Optimal growth was observed in the absence of $\mathrm{NaCl}$, but growth occurred with $\mathrm{NaCl}$ at concentrations up to $0.5 \%$, w/v (data not shown).

Strain $16628^{\mathrm{T}}$ was tested for the ability to oxidize a variety of inorganic electron donors with $\mathrm{O}_{2}(4 \%, \mathrm{v} / \mathrm{v})$ or nitrate (as $\mathrm{NaNO}_{3} ; 0.1 \%, \mathrm{w} / \mathrm{v}$ ) serving as the terminal electron acceptors. Donors tested included $\mathrm{H}_{2}(145 \mathrm{kPa}), \mathrm{S}^{0}$ (3\%, w/v), thiosulfate (as $\mathrm{Na}_{2} \mathrm{~S}_{2} \mathrm{O}_{3} \cdot 5 \mathrm{H}_{2} \mathrm{O} ; 0.1 \%$, w/v), sulfite (as $\mathrm{NaSO}_{3} ; 0.1 \%$, w/v), arsenite (as $\mathrm{NaAsO}_{2} ; 5 \mathrm{mM}$ ), selenite (as $\mathrm{Na}_{2} \mathrm{SeO}_{3} ; 5 \mathrm{mM}$ ) and $\mathrm{Fe}^{2+}$ (as $\mathrm{FeCl}_{2} .4 \mathrm{H}_{2} \mathrm{O}$; $5 \mathrm{mM}$ ). Growth was observed only with $\mathrm{H}_{2}, \mathrm{~S}^{0}$ and $\mathrm{S}_{2} \mathrm{O}_{3}^{2-}$ in the presence of $\mathrm{O}_{2}$. A variety of inorganic electron acceptors were also tested with $\mathrm{H}_{2}(145 \mathrm{kPa})$ as the electron donor, and included $S^{0}\left(3 \%\right.$, w/v), $\mathrm{O}_{2}(1-25 \%$, $\mathrm{v} / \mathrm{v})$, thiosulfate $(0.1 \%, \mathrm{w} / \mathrm{v})$, sulfite $(0.1 \%, \mathrm{w} / \mathrm{v})$, nitrate (as $\left.\mathrm{NaNO}_{3} ; 0.1 \%, \mathrm{w} / \mathrm{v}\right)$, nitrite $\left(\right.$ as $\mathrm{NaNO}_{2} ; 0.01$ and $0.1 \%$, $\mathrm{w} / \mathrm{v}$ ), $\mathrm{Fe}^{3+}$ (as ferric citrate; $5 \mathrm{mM}$ ), arsenate (as $\mathrm{Na}_{2} \mathrm{HAsO}_{4} \cdot 7 \mathrm{H}_{2} \mathrm{O} ; 5 \mathrm{mM}$ ) and selenate (as $\mathrm{Na}_{2} \mathrm{SeO}_{4}$; $5 \mathrm{mM}$ ). Strain $\mathrm{I}_{6628^{\mathrm{T}}}$ was able to utilize only $\mathrm{O}_{2}$ (up to $25 \%)$ as a terminal electron acceptor, showing optimal growth between 4 and $9 \%$ (data not shown).

To test the novel isolate for heterotrophic and fermentative growth, a variety of organic carbon sources were added to modified MS medium in the absence of $\mathrm{CO}_{2}, \mathrm{~S}^{0}$ and $\mathrm{S}_{2} \mathrm{O}_{3}^{2-}$. Growth was monitored in the presence and absence of both $\mathrm{O}_{2}$ as an electron acceptor and $\mathrm{H}_{2}$ as an electron donor. Potential energy substrates and carbon sources were added at 0.1 and $0.01 \%(\mathrm{w} / \mathrm{v} ; \mathrm{v} / \mathrm{v}$ for liquids) and included yeast extract, Bacto peptone, trypticase peptone, sucrose, glucose, starch, sodium formate, Casamino acids, formaldehyde, formamide, sodium citrate, sodium propionate, sodium acetate, 2-propanol, mannose, succinate and oxalate (Aguiar et al., 2004). Cultures that exhibited growth were transferred at least twice to ensure that growth was not the result of carry-over from the initial transfer. Strain $\mathrm{I} 6628^{\mathrm{T}}$ was only able to utilize succinate as a carbon source with $\mathrm{H}_{2}$ as an electron donor and $\mathrm{O}_{2}$ as an acceptor. The results of all of the growth experiments and comparisons with other Sulfurihydrogenibium isolates are summarized in Table 1.

Genomic DNA used for sequencing and $G+C$ content determination was extracted from a 11 culture by using the
Qiagen Genomic-tip 100/G DNA extraction kit according to the manufacturer's protocol for bacterial culture preparations. The thermal denaturation method (Marmur \& Doty, 1962) was used to determine the genomic $\mathrm{G}+\mathrm{C}$ content of strain $16628^{\mathrm{T}}$. The DNA G $+\mathrm{C}$ content of strain $\mathrm{I} 6628^{\mathrm{T}}$ was found to be $28.1 \mathrm{~mol} \%$, which is the lowest value reported for any described Sulfurihydrogenibium species (Table 1).

Amplification of the 16S rRNA gene and subsequent purification and sequencing were conducted as described previously (Ferrera et al., 2007). An almost-complete $16 \mathrm{~S}$ rRNA gene sequence (1486 nt) was assembled using the software AUTOASSEMBLER and was compared, using BLAST, against the NCBI non-redundant database. The ARB program (http://www.arb-home.de; Ludwig et al., 2004) was used to align the 16S rRNA gene sequences according to secondary structure constraints. A similarity matrix using $1430 \mathrm{nt}$ was constructed using a subset of closely related Sulfurihydrogenibium species. Strain $16628^{\mathrm{T}}$ is most closely related to the $16 \mathrm{~S}$ rRNA gene sequence of an environmental isolate from Iceland, designated strain SRI240 (99.5\% sequence similarity; Skirnisdottir et al., 2000). Only unambiguous nucleotide positions were used in the phylogenetic analysis ( 1300 bp). Neighbour-joining (1000 bootstrap replications) and maximum-likelihood (100 bootstrap replications) analyses (PAUP ${ }^{\star} 4.0$ beta 10 ; Swofford, 2003) were performed as described previously (Ferrera et al., 2007) (Fig. 2).

On the basis of the 16S rRNA gene sequence analysis, strain $16628^{\mathrm{T}}$ forms a distinct clade within the Sulfurihydrogenibium group $(99 \%$ maximum-likelihood bootstrap value) with the sequence of an environmental clone (SRI240; Skirnisdottir et al., 2000) from an Icelandic hot spring, and represents a novel cultivated species within this genus. Of the species of Sulfurihydrogenibium isolated to date, the strain closest to $\mathrm{I} 6628^{\mathrm{T}}$ is S. rodmanii $\mathrm{UZZ}-5^{\mathrm{T}}(98.2 \% 16 \mathrm{~S}$ rRNA gene sequence similarity) (Fig. 2), which was isolated from Kamchatka, Russia. Strain I6628 ${ }^{\mathrm{T}}$ shows $16 \mathrm{~S}$ rRNA gene sequence similarities of $98,97.5$ and $96 \%$ with respect to $S$. azorense $\mathrm{Az}-\mathrm{Fu} 1^{\mathrm{T}}$, S. subterraneum $\mathrm{HGMK}-1^{\mathrm{T}}$ and $S$. yellowstonense SS $-5^{\mathrm{T}}$ (Fig. 2), respectively.

The members of the Aquificales appear to be the predominant primary producers in circumneutral terrestrial hot-spring streams at temperatures above the limits for photosynthesis (Reysenbach et al., 2005; Spear et al., 2005) and in conditions where hydrogen, sulfur/sulfide and oxygen are readily available. Micro-organisms belonging to the genus Sulfurihydrogenibium tend to be the predominant members of the Aquificales present in circumneutral terrestrial springs with elevated sulfide concentrations. This situation contrasts with that found in low-sulfide springs, in which other members of the Aquificales that preferentially oxidize hydrogen, e.g. Thermocrinis and Hydrogenobacter, predominate (Skirnisdottir et al., 2000); both Thermocrinis and Hydrogenobacter can also oxidize reduced sulfur compounds (Huber et al., 1998; Stöhr et al., 
Table 1. Comparison of physiological traits of strain $16628^{\top}$ and described members of the genus Sulfurihydrogenibium

\begin{tabular}{|c|c|c|c|c|c|}
\hline Characteristic & Strain $\mathrm{I} 6628^{\mathrm{T}}$ & S. rodmanii UZ3-5 $5^{\mathrm{T}}$ & S. yellowstonense SS- $5^{\mathrm{T}}$ & S. azorense $\mathrm{Az}-\mathrm{Fu} 1^{\mathrm{T}}$ & S. subterraneum HGMK-1 ${ }^{\mathrm{T}}$ \\
\hline Origin & Terrestrial hot spring, Iceland & $\begin{array}{l}\text { Terrestrial hot spring, } \\
\text { Kamchatka, Russia }\end{array}$ & $\begin{array}{l}\text { Terrestrial hot spring, } \\
\text { Yellowstone National Park, USA }\end{array}$ & $\begin{array}{r}\text { Terrestrial hot spring, } \\
\text { the Azores, Portugal }\end{array}$ & $\begin{array}{l}\text { Subsurface gold mine, } \\
\text { Hishikari, Japan }\end{array}$ \\
\hline $\begin{array}{l}\text { Cell size }(\mu \mathrm{m}) \\
\text { (length } \times \text { width })\end{array}$ & $1.5-2.5 \times 0.4-0.5$ & $1.19-1.42 \times 0.72-0.79$ & $1.2-2.8 \times 0.6-0.8$ & $0.9-2.0 \times 0.4-0.5$ & $1.5-2.5 \times 0.3-0.5$ \\
\hline $\begin{array}{l}\text { Temperature range } \\
\text { (optimum) }\left({ }^{\circ} \mathrm{C}\right)\end{array}$ & $40-73(68)$ & $55-80(74-75)$ & $55-78(70)$ & $50-73(68)$ & $40-70(65)$ \\
\hline $\mathrm{pH}$ range (optimum) & $5.3-7.8(6.6)$ & $5.0-7.0(5.5-6.47)$ & $6.0-8.0(7.5)$ & $5.5-7.0(6.0)$ & $6.4-8.8(7.5)$ \\
\hline $\begin{array}{l}\mathrm{NaCl} \text { range (optimum) } \\
(\%, \mathrm{v} / \mathrm{w})\end{array}$ & $0-0.5(0)$ & $0-0.9(0)$ & $0-0.6(0)$ & $0-0.25(0.1)$ & $0-4.8(0.5)$ \\
\hline Electron acceptor(s) & $\mathrm{O}_{2}$ (up to $25 \%$, v/v) & $\mathrm{O}_{2}($ up to $14 \%, \mathrm{v} / \mathrm{v})$ & $\mathrm{O}_{2}$ (up to $18 \%$, v/v) & $\begin{array}{c}\left.\mathrm{S}^{0}, \mathrm{Fe}^{3+}, * \mathrm{O}_{2} \text { (up to } 9 \%, \mathrm{v} / \mathrm{v}\right), \\
\mathrm{SO}_{3}^{2-}, \mathrm{AsO}_{4}^{3-,}, \mathrm{SeO}_{4}^{2-*}\end{array}$ & $\begin{array}{c}\mathrm{Fe}^{3+}, \mathrm{O}_{2}, \mathrm{NO}_{3}^{-}, \mathrm{HAsO}_{4}^{2-}, \\
\mathrm{SeO}_{4}^{2-}, \mathrm{SeO}_{3}^{2-}\end{array}$ \\
\hline $\begin{array}{l}\text { Organic carbon } \\
\text { source(s) }\end{array}$ & $\begin{array}{l}\text { Succinate (with } \mathrm{H}_{2} \\
\text { as electron donor) }\end{array}$ & None & $\begin{array}{l}\text { Yeast extract, Bacto peptone, trypticase } \\
\text { peptone, sucrose, glucose, starch, } \\
\text { formate, Casamino acids, citrate, } \\
\text { propionate, acetate }\end{array}$ & $\begin{array}{l}\text { Yeast extract, Bacto peptone, } \\
\text { trypticase peptone, Casamino } \\
\text { acids }\end{array}$ & Acetate \\
\hline
\end{tabular}

${ }^{*}$ We have recently had difficulty growing this organism under these conditions. 


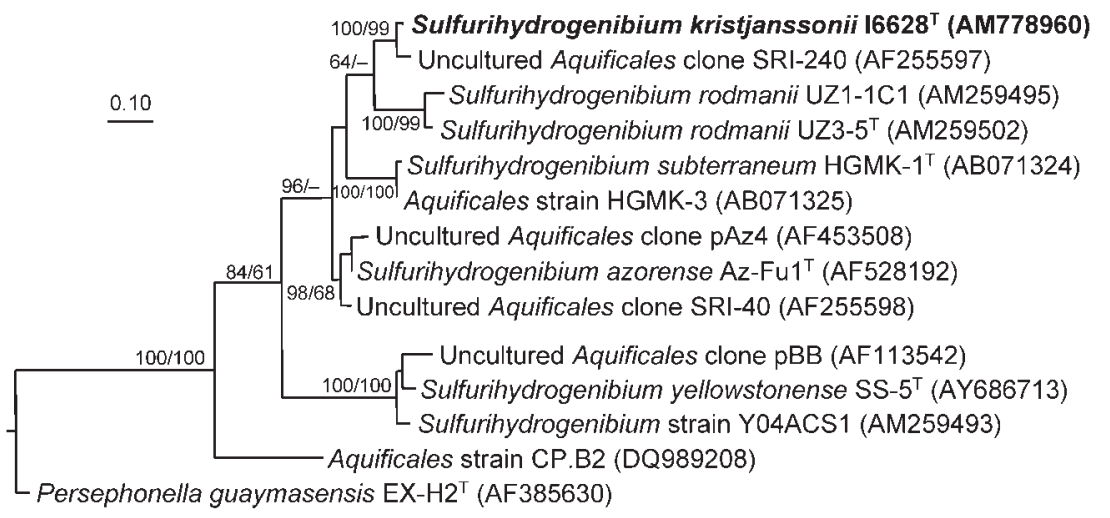

Fig. 2. Maximum-likelihood phylogenetic tree, based on $16 \mathrm{~S}$ rRNA gene sequences, showing the position of strain $16628^{\top}$ relative to members of the Aquificales. Bootstrap percentages above $50 \%$ are shown firstly for the neighbour-joining analyses (based on 1000 replicates) and secondly for the maximum-likelihood analysis (based on 100 replicates). Additional sequences used to generate the tree (not shown) were from Aquifex pyrophilus Kol5a ${ }^{\top}$ (GenBank accession no. M83548), Hydrogenobacter subterraneus $\mathrm{HGP}^{\top}$ (AB026268), Thermocrinis ruber OC 1/4 ${ }^{\top}$ (AJ005640), Persephonella marina EX$\mathrm{H}^{\top}{ }^{\top}$ (AF188332), Persephonella hydrogeniphila 29W $\mathrm{W}^{\top}$ (AB086419), Desulfurobacterium thermolithotrophum BSA ${ }^{\top}$ (AJ001049) and Thermotoga maritima MSB8 ${ }^{\top}$ (M21774). The sequence of Methanocaldococcus jannaschii DSM 2661 ${ }^{\top}$ (GenBank accession no. M59126) was used as the outgroup to root the tree (not shown). Bar, 10 substitutions per 100 nucleotides.

2001; Eder \& Huber 2002). However, it appears that Sulfurihydrogenibium species might be more adapted to high-sulfide environments and are able to outcompete other members of the Aquificales (Skirnisdottir et al., 2000). Furthermore, some isolates, e.g. S. yellowstonense $\mathrm{SS}-5^{\mathrm{T}}$, lack the suite of hydrogenases present in 'Aquifex aeolicus' VF5 and S. azorense Az-Fu1 ${ }^{\mathrm{T}}$ (A.-L. Reysenbach, unpublished results). The isolation of strain $16628^{\mathrm{T}}$ under sulfur-oxidizing conditions serves to illustrate the importance of sulfide to the physiological ecology of the genus Sulfurihydrogenibium.

Strain I6628 ${ }^{\mathrm{T}}$ shares several of the physiological properties associated with recognized species of the genus Sulfurihydrogenibium, including the preference for low concentrations of $\mathrm{NaCl}$ and $\mathrm{O}_{2}$ and the ability to oxidize $\mathrm{S}^{0}$ and $\mathrm{S}_{2} \mathrm{O}_{3}^{2-}$ (Table 1). In contrast, only three of the described isolates, strain $16628^{\mathrm{T}}$, S. azorense Az-Fu1 ${ }^{\mathrm{T}}$ (Aguiar et al., 2004) and S. subterraneum HGMK-1 ${ }^{\mathrm{T}}$ (Takai et al., 2003), can oxidize $\mathrm{H}_{2}$. Additionally, only $\mathrm{I}_{6} 628^{\mathrm{T}}$, S. rodmanii UZ3-5 ${ }^{\mathrm{T}}$ (O’Neill et al., 2008) and $S$. yellowstonense SS $-5^{\mathrm{T}}$ (Nakagawa et al., 2005) use only $\mathrm{O}_{2}$ as an electron acceptor. Strain $16628^{\mathrm{T}}$ also possesses heterotrophic capabilities similar to those of $S$. azorense $\mathrm{Az}-\mathrm{Fu} 1^{\mathrm{T}}$, S. subterraneum HGMK- $1^{\mathrm{T}}$ and S. yellowstonense $\mathrm{SS}-5^{\mathrm{T}}$, but is much more restricted, using only succinate as an organic carbon source. Therefore, it appears that strain $16628^{\mathrm{T}}$ possesses a combination of the physiological capabilities of all Sulfurihydrogenibium species described to date. On the basis of these phylogenetic and physiological characteristics, strain $16628^{\mathrm{T}}$ represents a novel species of the genus Sulfurihydrogenibium, for which the name Sulfurihydrogenibium kristjanssonii sp. nov. is proposed.

\section{Description of Sulfurihydrogenibium kristjanssonii sp. nov.}

Sulfurihydrogenibium kristjanssonii (krist.jans'son.i.i. N.L. masc. gen. n. kristjanssonii of Kristjansson, in honour of Jakob Kristjansson for his long-term commitment to the description and exploration of thermophile biodiversity in Iceland, which includes some of the first work done on the Aquificales).

Cells are motile, Gram-negative, straight to slightly curved rods with mean lengths of $1.5-2.5 \mu \mathrm{m}$ and widths of approximately $0.5 \mu \mathrm{m}$. Occur singly or in filaments consisting of a few cells. Grows between 40 and $73{ }^{\circ} \mathrm{C}$ (optimally at $68{ }^{\circ} \mathrm{C}$ ), between pH 5.3 and 7.8 (optimally at $\mathrm{pH}$ 6.6) and at $\mathrm{NaCl}$ concentrations between 0 and $0.5 \%$ (w/v). Grows with $\mathrm{H}_{2}, \mathrm{~S}^{0}$ and $\mathrm{S}_{2} \mathrm{O}_{3}^{2-}$ as electron donors and $\mathrm{O}_{2}$ as sole electron acceptor (up to $25 \%, \mathrm{v} / \mathrm{v}$ ). Facultatively heterotrophic, being capable of using succinate and $\mathrm{CO}_{2}$ as carbon sources. The $\mathrm{G}+\mathrm{C}$ content of the genomic DNA of the type strain is $28.1 \mathrm{~mol} \%$.

The type strain, $16628^{\mathrm{T}}\left(=\mathrm{DSM} 19534^{\mathrm{T}}=\mathrm{OCM} 901^{\mathrm{T}}\right.$ $=$ ATCC BAA- $1535^{\mathrm{T}}$ ), was isolated from the outflow channel of a hot spring near the town of Hveragerdi, Iceland.

\section{Acknowledgements}

The authors would like to thank Jakob Kristjansson, Viggo Marteinsson and Mary Voytek for their help with field work and sample collection. We would also like to thank Dianne Moyles (University of Guelph) for her assistance with the electron microscopy. The research was supported by an NSF-PEET grant (DEB-0328326) to A.-L. R. The electron microscopy was performed in the NSERC Guelph Regional Integrated Imaging Facility (GRIIF), 
which is partially funded by an NSERC Major Facility Access grant (to T. J. B.).

\section{References}

Aguiar, P., Beveridge, T. J. \& Reysenbach, A.-L. (2004). Sulfurihydrogenibium azorense sp. nov., a thermophilic hydrogenoxidizing microaerophile from terrestrial hot springs in the Azores. Int J Syst Evol Microbiol 54, 33-39.

Barion, S., Franchi, M., Gallori, E. \& Di Giulio, M. (2007). The first lines of divergence in the Bacteria domain were the hyperthermophilic organisms, the Thermotogales and the Aquificales, and not the mesophilic Planctomycetales. Biosystems 87, 13-19.

Beveridge, T. J., Moyles, D. \& Harris, R. (2007). Electron microscopy. In Methods for General and Molecular Microbiology, 2nd edn, pp. 5481. Edited by C. A. Reddy, T. J. Beveridge, J. A. Breznak, L. Snyder, T. M. Schmidt \& G. A. Marzluf. Washington, DC: American Society for Microbiology.

Boone, D. R., Johnson, R. L. \& Liu, Y. (1989). Diffusion of the interspecies electron carriers $\mathrm{H}_{2}$ and formate in methanogenic ecosystems and its implications in the measurement of $K_{\mathrm{m}}$ for $\mathrm{H}_{2}$ or formate uptake. Appl Environ Microbiol 55, 1735-1741.

Burggraf, S., Olsen, G. J., Stetter, K. O. \& Woese, C. R. (1992). A phylogenetic analysis of Aquifex pyrophilus. Syst Appl Microbiol 15, 352-356.

Chong, S. C., Liu, Y., Cummins, M., Valentine, D. L. \& Boone, D. R. (2002). Methanogenium marinum sp. nov., a $\mathrm{H}_{2}$-using methanogen from Skan Bay, Alaska, and kinetics of $\mathrm{H}_{2}$ utilization. Antonie van Leeuwenhoek 81, 263-270.

Di Giulio, M. (2003a). The ancestor of the Bacteria domain was a hyperthermophile. J Theor Biol 224, 277-283.

Di Giulio, M. (2003b). The universal ancestor and the ancestor of the Bacteria were hyperthermophiles. J Mol Evol 57, 721-730.

Di Giulio, M. (2003c). The universal ancestor was a thermophile or a hyperthermophile: tests and further evidence. J Theor Biol 221, 425-436.

Eder, W. \& Huber, R. (2002). New isolates and physiological properties of the Aquificales and description of Thermocrinis albus ap. nov. Extremophiles 6, 309-318.

Ferguson, T. J. \& Mah, R. A. (1983). Isolation and characterization of an $\mathrm{H}_{2}$-oxidizing methanogen. Appl Environ Microbiol 45, 265-274.

Ferrera, I., Longhorn, S., Banta, A. B., Liu, Y., Preston, D. \& Reysenbach, A.-L. (2007). Diversity of $16 \mathrm{~S}$ rRNA gene, ITS region and aclB gene of the Aquificales. Extremophiles 11, 57-64.

Götz, D., Banta, A., Beveridge, T. J., Rushdi, A. I., Simoneit, B. R. T. \& Reysenbach, A.-L. (2002). Persephonella marina gen. nov., sp nov. and Persephonella guaymasensis sp. nov., two novel, thermophilic, hydrogen-oxidizing microaerophiles from deep-sea hydrothermal vents. Int J Syst Evol Microbiol 52, 1349-1359.

Hetzer, A., Morgan, H. W., McDonald, I. R. \& Daughney, C. J. (2007). Microbial life in Champagne Pool, a geothermal spring in Waiotapu, New Zealand. Extremophiles 11, 605-614.

Huber, R., Eder, W., Heldwein, S., Wanner, G., Huber, H., Rachel, R. \& Stetter, K. O. (1998). Thermocrinis ruber gen. nov., sp. nov., a pinkfilament-forming hyperthermophilic bacterium isolated from Yellowstone National Park. Appl Environ Microbiol 64, 3576-3583.

Ludwig, W., Strunk, O., Westram, R., Richter, L., Meier, H., Yadhukumar, Buchner, A., Lai, T., Steppi, S. \& other authors
(2004). ARB: a software environment for sequence data. Nucleic Acids Res 32, 1363-1371.

Marmur, J. \& Doty, P. (1962). Determination of the base composition of deoxyribonucleic acid from its thermal denaturation temperature. J Mol Biol 5, 109-118.

Nakagawa, S., Shtaih, Z., Banta, A., Beveridge, T. J., Sako, Y. \& Reysenbach, A.-L. (2005). Sulfurihydrogenibium yellowstonense sp. nov., an extremely thermophilic, facultatively heterotrophic, sulfuroxidizing bacterium from Yellowstone National Park, and emended descriptions of the genus Sulfurihydrogenibium, Sulfurihydrogenibium subterraneum and Sulfurihydrogenibium azorense. Int J Syst Evol Microbiol 55, 2263-2268.

O’Neill, A. H., Liu, Y., Ferrera, I., Beveridge, T. J. \& Reysenbach, A.-L. (2008). Sulfurihydrogenibium rodmanii sp. nov., a sulfur-oxidizing chemolithoautotroph from the Uzon Caldera, Kamchatka, Russia, and emended description of the genus Sulfurihydrogenibium. Int J Syst Evol Microbiol 58, 1147-1152.

Pitulle, C., Yang, Y. Q., Marchiani, M., Moore, E. R. B., Siefert, J. L., Aragno, M., Jurtshuk, P. \& Fox, G. E. (1994). Phylogenetic position of the genus Hydrogenobacter. Int J Syst Bacteriol 44, 620-626.

Purcell, D., Sompong, U., Yim, L. C., Barraclough, T. G., Peerapornpisal, Y. \& Pointing, S. B. (2007). The effects of temperature, $\mathrm{pH}$ and sulphide on the community structure of hyperthermophilic streamers in hot springs of northern Thailand. FEMS Microbiol Ecol 60, 456-466.

Reysenbach, A.-L., Ehringer, M. \& Hershberger, K. (2000). Microbial diversity at $83^{\circ} \mathrm{C}$ in Calcite Springs, Yellowstone National Park: another environment where the Aquificales and "Korarchaeota" coexist. Extremophiles 4, 61-67.

Reysenbach, A.-L., Banta, A., Civello, S., Daly, J., Mitchel, K., Lalonde, S., Konhauser, K., Rodman, S., Rustenholtz, K. \& Takacs-Vesbach, C. (2005). The Aquificales of Yellowstone National Park. In Geothermal Biology and Geochemistry in Yellowstone National Park: Workshop Proceedings from the Thermal Biology Institute's Yellowstone National Park Conference, October 2003, pp. 129-142. Edited by W. P. Inskeep \& T. R. McDermott. Bozeman, MT: Montana State University.

Skirnisdottir, S., Hreggvidsson, G. O., Hjorleifsdottir, S., Marteinsson, V. T., Petursdottir, S. K., Holst, O. \& Kristjansson, J. K. (2000). Influence of sulfide and temperature on species composition and community structure of hot spring microbial mats. Appl Environ Microbiol 66, 2835-2841.

Spear, J. R., Walker, J. J., McCollom, T. M. \& Pace, N. R. (2005). Hydrogen and bioenergetics in the Yellowstone geothermal ecosystem. Proc Natl Acad Sci U S A 102, 2555-2560.

Stöhr, R., Waberski, A., Völker, H., Tindall, B. J. \& Thomm, M. (2001). Hydrogenothermus marinus gen. nov., sp. nov., a novel thermophilic hydrogen-oxidizing bacterium, recognition of Calderobacterium hydrogenophilum as a member of the genus Hydrogenobacter and proposal of the reclassification of Hydrogenobacter acidophilus as Hydrogenobaculum acidophiulm gen. nov., comb. nov., in the phylum 'Hydrogenobacter/Aquifex'. Int J Syst Evol Microbiol 51, 1853-1862.

Swofford, D. L. (2003). PAUP*: Phylogenetic analysis using parsimony (and other methods). Sunderland, MA: Sinauer Associates.

Takacs, C. D., Ehringer, M., Favre, R., Cermola, M., Eggertsson, G., Palsdottir, A. \& Reysenbach, A.-L. (2001). Phylogenetic characterization of the blue filamentous bacterial community from an Icelandic geothermal spring. FEMS Microbiol Ecol 35, 123-128.

Takai, K., Kobayashi, Y., Nealson, K. H. \& Horikoshi, K. (2003). Sulfurihydrogenibium subterraneum gen. nov., sp. nov., from a subsurface hot aquifer. Int J Syst Evol Microbiol 53, 823-827. 